\title{
Scabies and Pediculosis in Penitentiary Institutions in Poland-A Study of Ectoparasitoses in Confinement Conditions
}

\author{
Katarzyna Bartosik ${ }^{1, * \mathbb{D}}$, Andrzej Tytuła ${ }^{2}$, Zbigniew Zając ${ }^{1}{ }^{(}$, Weronika Buczek ${ }^{1}$, \\ Anita Jasztal-Kniażuk ${ }^{2}$, Paweł Szczepan Błaszkiewicz ${ }^{1}$ and Adam Borzęcki ${ }^{3}$ \\ 1 Chair and Department of Biology and Parasitology, Medical University of Lublin, Radziwiłłowska 11 St., \\ 20-080 Lublin, Poland; zbigniew.zajac@umlub.pl (Z.Z.); wera1301@gmail.com (W.B.); \\ blaszkiewicz_pawel@interia.pl (P.S.B.) \\ 2 Regional Chamber of Nurses and Midwives in Lublin, 20-072 Lublin, Poland; naszglos@o2.pl (A.T.); \\ ajasztal@op.pl (A.J.-K.) \\ 3 Med-Laser Non-Public Health Care Centre, 20-406 Lublin, Poland; laserlub@poczta.onet.pl \\ * Correspondence: katarzyna.bartosik@umlub.pl
}

Received: 1 July 2020; Accepted: 19 August 2020; Published: 21 August 2020

\begin{abstract}
Background: Scabies (caused by Sarcoptes scabiei var. hominis) and pediculosis (caused by Pediculus humanus) are infectious diseases common in educational institutions and long-term care centres. The aim of the study was to assess the scale of the phenomenon in confinement conditions favouring the spread of these parasitoses. Methods: Data on the prevalence of scabies (2001-2015) and pediculosis (2008-2015) in Polish prisoners were provided by the Central Board of Prison Service. The information for the period between 2010 and 2015 in the Lublin Province was obtained from the District Inspectorate of the Prison Service in Lublin. Correlations between the prevalence of scabies and pediculosis and the number of prisoners were analysed, as well as correlations between the number of passes granted to prisoners and the prevalence of scabies and pediculosis in incarcerated individuals. Results: The prevalence of scabies and pediculosis in Polish prisoners has been estimated at $2.3 \%$ and $1.9 \%$, respectively. Conclusions: Pediculosis and scabies are still current issues in Polish prisons. Convicts returning from passes and new prisoners should be carefully examined and monitored for the presence of S. scabiei var. hominis and P. humanus invasion. Education of prisoners could be a promising tool in prevention of scabies and pediculosis in correctional settings.
\end{abstract}

Keywords: Sarcoptes scabiei var. hominis; scabies; Pediculus humanus; pediculosis; neglected parasitic diseases; prisoner's health; social stigma

\section{Introduction}

Scabies and pediculosis are parasitic dermatoses caused by mites (Sarcoptes scabiei var. hominis) and insects (Pediculus humanus), respectively (Figure 1). These parasitic infections are some of the major public health problems not only in low and middle-income countries but also in highly developed ones [1-6]. The risk of parasite transmission is especially high in non-medical public and private facilities (e.g., long-term care facilities, hospitals, adult day care centres, schools, military facilities, and prisons). These facilities provide a special environment for parasite transmission, fostering frequent, close, and often intimate human-to-human contacts between residents. Factors that promote person-to-person transmission include close living quarters; a poor level of self-hygiene; sharing of fomites, e.g., combs and head gear; and sometimes a depressed mental state of residents [7]. High patient-to-staff ratios, high staff turnover, and inadequate implementation of infection control policies are challenges to the control of infections in non-medical public and private 
facilities [8,9]. In some countries (including Poland), reporting of scabies or pediculosis infection to local sanitary-epidemiological stations is not mandatory according to the law. Thus, the real scale of these parasitic infections is hard to assess. Previous studies estimated the prevalence of head lice around the globe in a range of $0.7-61.4 \%$ [10]. The overall worldwide prevalence of S. scabiei var. hominis infection ranges from $0.2 \%$ to $71.4 \%$ [11]. In highly developed countries, scabies infection occurs mainly in institutional settings such as hospitals, nursing houses, and prisons [8,12]. It is believed that confinement conditions favour the spread of ectoparasites, which necessitates rigorous hygienic control in penitentiary institutions. The aim of this study was to assess the prevalence of P. humanus and S. scabiei var. hominis infestation in confinement conditions under constant medical supervision in a period when reporting these parasitoses was no longer mandatory.

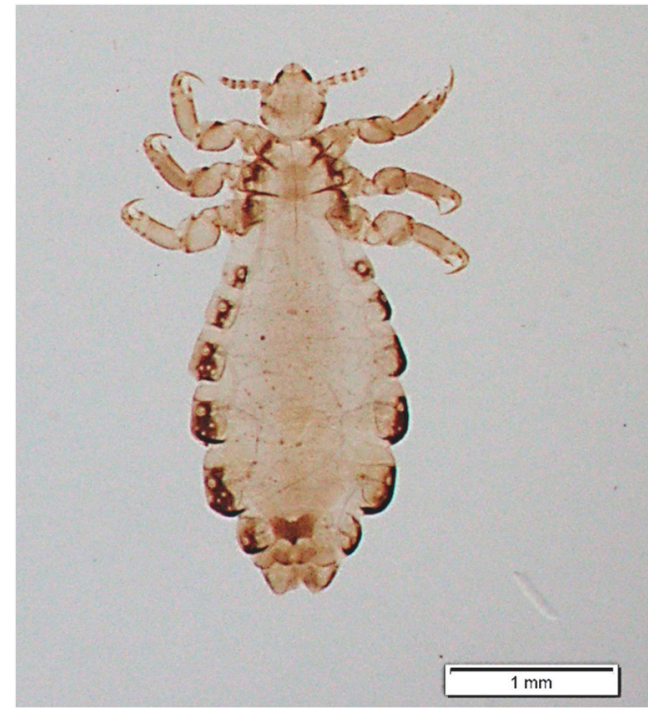

(a)

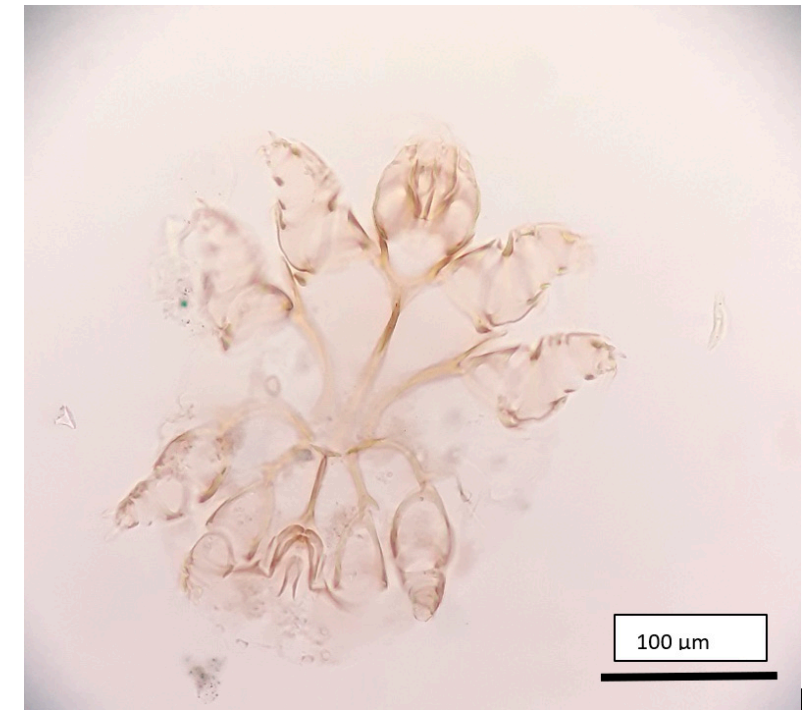

(b)

Figure 1. Pediculus humanus (a) and Sarcoptes scabiei var. hominis (b) (photographs by K. Bartosik).

\section{Materials and Methods}

\subsection{Data Collection}

The analysis of the prevalence of scabies and pediculosis in individuals residing in confinement conditions in Poland was based on epidemiological data collected in prisons both at the national and regional level (Figure 2). In these institutions, the ectoparasitoses are registered in compliance with internal procedures despite the lack of a statutory obligation to report their occurrence. Data on the prevalence of scabies (2001-2015) and pediculosis (2008-2015) in Polish prisoners were provided by the Central Board of Prison Service, while the information for the period between 2010 and 2015 in the Lublin Province was obtained from the District Inspectorate of the Prison Service in Lublin. The information on the number of passes granted to prisoners in 2001-2015 was taken from the Annual Statistical Information published online by the Ministry of Justice and the Central Board of the Prison Service. The constant monitoring of the statistics of pediculosis and scabies in penitentiary institutions imposed by the internal regulations of the prison service provides reliable information on the prevalence of these parasitoses in prisoners.

The data sets prepared by prison staff do not differentiate between pediculosis capitis and pediculosis corporis and include both invasions caused by Pediculus humanus capitis and Pediculus humanus corporis. Since our study was retrospective and non-invasive and all data were anonymous, no Ethics Committee approval was required. 


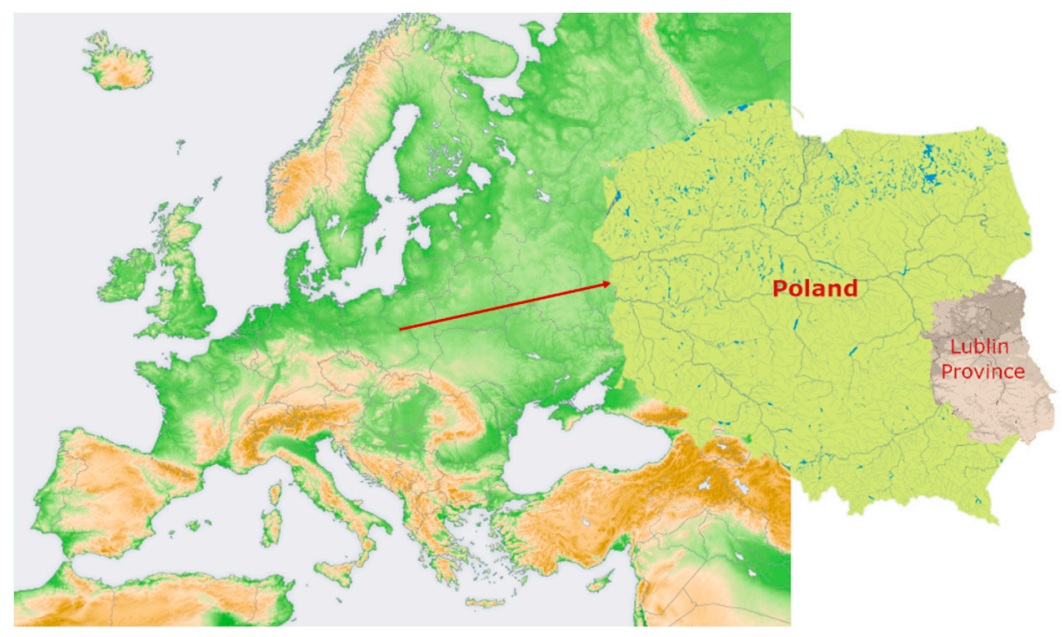

Figure 2. Study area at the national (Poland) and regional (Lublin Province) level, based on Wikimedia with our modifications.

\subsection{Statistical Analysis}

Analysis of the data was performed using statistical package PQStat ver. 1.4.2.324 (PQStat Software, Poznan, Poland). The correlation between the number of imprisoned individuals and scabies and pediculosis cases in the study period was analysed by estimation of Spearman's rank correlation coefficient $\left(\mathrm{r}_{\mathrm{s}}\right)$. Probability was considered significant at $p<0.05$ and highly significant at $p<0.01$. At the national level, the correlation between the number of periodic passes granted to prisoners and the number of reported cases of scabies and pediculosis among prisoners was examined using the Pearson correlation coefficient.

\section{Results}

As demonstrated by data from 2001-2015, the average annual number of scabies cases in the study period was 1930 (Table 1).

Table 1. Prevalence of scabies in Polish prisoners in 2001-2015 in relation to the number of imprisoned individuals and the number of cases noted.

\begin{tabular}{cccc}
\hline \multirow{2}{*}{ Years } & Number of Prisoners $\mathbf{1}^{\mathbf{1}}$ & \multicolumn{2}{c}{ Scabies } \\
\cline { 3 - 4 } & & Number of Cases & Prevalence \\
\hline 2001 & 78,716 & 3072 & $3.9 \%$ \\
2002 & 81,391 & 3071 & $3.8 \%$ \\
2003 & 81,321 & 2324 & $2.9 \%$ \\
2004 & 80,239 & 1833 & $2.3 \%$ \\
2005 & 82,761 & 1455 & $1.8 \%$ \\
2006 & 87,370 & 1245 & $1.4 \%$ \\
2007 & 89,995 & 1115 & $1.2 \%$ \\
2008 & 85,920 & 1103 & $1.3 \%$ \\
2009 & 85,384 & 1172 & $1.4 \%$ \\
2010 & 82,863 & 1387 & $1.7 \%$ \\
2011 & 82,558 & 2029 & $2.5 \%$ \\
2012 & 84,399 & 2121 & $2.5 \%$ \\
2013 & 83,898 & 2455 & $2.9 \%$ \\
2014 & 78,987 & 2465 & $3.1 \%$ \\
2015 & 74,814 & 2096 & $2.8 \%$ \\
\hline & & Total 28,943 & $\mathbf{M} * \mathbf{2 . 3} \%$ \\
\hline
\end{tabular}

${ }^{1}$ In $2001-2015$, foreigners constituted on average $0.96 \%$ (from $0.65 \%$ to $2.03 \%$ ) of the inmates. ${ }^{*}$ Mean. 
As shown by the trend line, the lowest number of scabies cases was recorded in 2007-2008, i.e., 1115 and 1103 cases, and the highest prevalence was noted in 2001-2002, i.e., 3072 and 3071 cases of the parasitosis (Figure 3a, Table 1). After 2003, the prevalence of infections gradually declined until 2010. Next, the number of reported scabies cases increased again. The graph shows a polynomial trend line. The median of the number of scabies cases in the study period was 2029 (SD =627).

Based on the general data on the number of prisoners and the number of scabies infections, the prevalence (i.e., the extensiveness of infection) of scabies was calculated for the study years (Table 1). The highest prevalence of scabies was recorded in 2001, 2002, and 2014 (over 3\% in relation to the total number of prisoners). The lowest percentage of infections was recorded in 2006-2010.

The higher number of prisoners in the analysed years (2001-2015) was not correlated to an increase in the prevalence of scabies: the greater the number of prisoners, the lower the number of infection cases (Rho Spearman $=-0.718 ; p=0.003)$.

a- Scabies

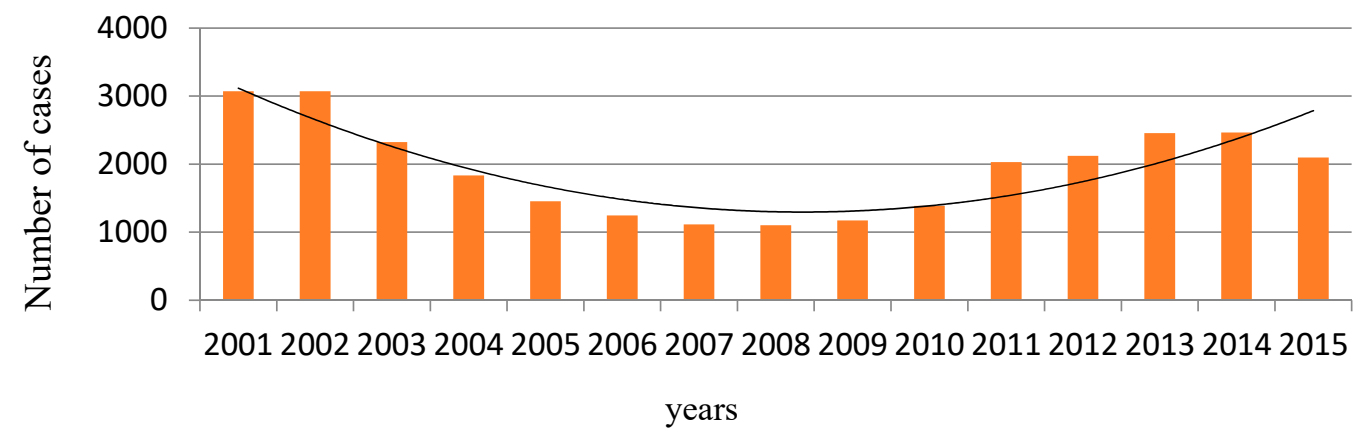

b- Pediculosis

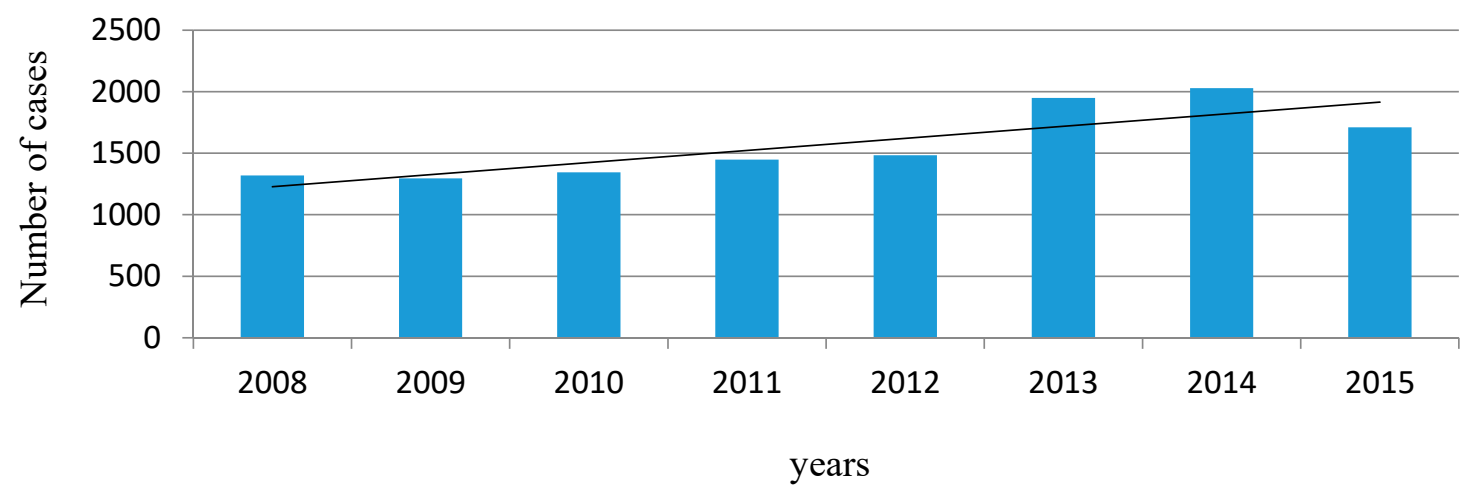

Figure 3. Number of cases of scabies and pediculosis with trend lines in Polish prisoners: (a) scabies in 2001-2015, (b) pediculosis in 2008-2015 (source: annual information, Central Board of Prison Service).

The average number of cases of pediculosis among the prisoners in the analysed years was 1572. The highest and the lowest numbers of cases of the disease were recorded in 2014 and in 2009. From 2009, there was an increasing trend in pediculosis prevalence among the prisoners, which persisted until 2014. Decreasing prevalence of pediculosis was only noted in 2015 (Figure 3b).

As indicated above, the highest number of pediculosis cases, i.e., 2029, was reported in 2014, whereas the lowest number, i.e., 1296 cases, was noted in 2009 (Figure 3b, Table 2). The median of the number of pediculosis cases was calculated at $1466(\mathrm{SD}=289)$. Based on general data on the number of prisoners and the number of pediculosis infections, the prevalence of the parasitism among prisoners was calculated in the study years, as in the case of scabies infection (Table 2). The highest percentage of pediculosis was recorded in 2013 and 2015 (over 2\% in each year). There was no correlation between 
the number of prisoners and the prevalence of $P$. humanus invasion $\left(\mathrm{r}_{\mathrm{s}}=-0.667 ; \mathrm{p}=0.071\right)$. A negative correlation between the total number of passes granted to prisoners and the incidence of head lice $\left(r_{\mathrm{s}}=-0.6933\right)$ and scabies $\left(\mathrm{r}_{\mathrm{s}}=-0.7822\right)$ was noted.

The scale of the problem was analysed for the Lublin region as well. The data from the Regional Inspectorate of the Prison Service in Lublin originated from 2010-2015. Based on these data, it was concluded that the problem of scabies and pediculosis in 2010-2015 afflicted less than 1\% of the prisoners in our Province. Throughout the study period, the prevalence of scabies and pediculosis was within the range of $0.3-1.0 \%$ and $0.1-1.1 \%$, respectively (Table 3).

Table 2. Prevalence of pediculosis in Polish prisoners in 2008-2015 in relation to the number of imprisoned individuals and the number of cases noted.

\begin{tabular}{cccc}
\hline \multirow{2}{*}{ Years } & Number of Prisoners $\mathbf{1}$ & \multicolumn{2}{c}{ Pediculosis } \\
\cline { 3 - 4 } & & Number of Cases & Prevalence \\
\hline 2008 & 85,920 & 1319 & $1.5 \%$ \\
2009 & 85,384 & 1296 & $1.5 \%$ \\
2010 & 82,863 & 1344 & $1.6 \%$ \\
2011 & 82,558 & 1448 & $1.8 \%$ \\
2012 & 84,399 & 1484 & $1.8 \%$ \\
2013 & 83,898 & 1949 & $2.3 \%$ \\
2014 & 78,987 & 2029 & $2.6 \%$ \\
2015 & 74,814 & 1710 & $2.3 \%$ \\
\hline & & Total $\mathbf{1 2 , 5 7 9}$ & $\mathbf{M}$ * $\mathbf{1 . 9} \%$ \\
\hline${ }^{1}$ In $2008-2015$, foreigners constituted on average $0.67 \%$ (from 0.65 to $\left.0.72 \%\right)$ of inmates. ${ }^{*}$ Mean
\end{tabular}

Table 3. Prevalence of scabies and pediculosis in prisoners in relation to the number of imprisoned individuals and cases noted in Lublin Province (2010-2015).

\begin{tabular}{|c|c|c|c|c|c|}
\hline \multirow{2}{*}{ Years } & \multirow{2}{*}{ Number of Prisoners } & \multicolumn{2}{|c|}{ Scabies } & \multicolumn{2}{|c|}{ Pediculosis } \\
\hline & & Number of Cases & Prevalence & Number of Cases & Prevalence \\
\hline 2010 & 4301 & 12 & $0.3 \%$ & 9 & $0.2 \%$ \\
\hline 2011 & 4261 & 39 & $0.9 \%$ & 6 & $0.1 \%$ \\
\hline 2012 & 4569 & 46 & $1.0 \%$ & 32 & $0.7 \%$ \\
\hline 2013 & 4397 & 41 & $0.9 \%$ & 49 & $1.1 \%$ \\
\hline 2014 & 4336 & 33 & $0.8 \%$ & 36 & $0.8 \%$ \\
\hline \multirow[t]{3}{*}{2015} & 4001 & 31 & $0.8 \%$ & 32 & $0.8 \%$ \\
\hline & & Total 202 & $M * 0.8 \%$ & Total 164 & $M * 0.6 \%$ \\
\hline & & \multicolumn{2}{|c|}{$\begin{aligned} \mathrm{r}_{\mathrm{s}} & =0.714 \\
\mathrm{p} & =0.111\end{aligned}$} & \multicolumn{2}{|c|}{$\mathrm{r}_{\mathrm{s}}=0.522 ; \mathrm{p}=0.288$} \\
\hline
\end{tabular}

\section{Discussion}

Scabies and pediculosis are parasitic diseases spreading easily in confinement conditions [8,9,12-15]. In 2008-2015 in Poland, there were on average 82,708 prisoners in penitentiary institutions; scabies and pediculosis were diagnosed in $2.3 \%$ and $1.9 \%$ of the total number of prisoners, respectively. This percentage was significantly lower in the prisoners in the Lublin Province, i.e., $0.8 \%$ and $0.6 \%$, respectively. The problem of skin parasitoses afflicts primarily male prisoners, since males constitute a majority of convicts in Poland (ca. 96\%). These are more often middle-aged men (30-39 years old) and, to a lesser extent, young people below 20 years of age. Due to the changes in legal regulations introduced in 2008 and abolishing the obligation to report pediculosis cases by general practitioners and health care centres to relevant sanitary supervision units, only data from research studies, mainly involving schoolchildren, can serve as a reference point. 
The level of head lice infestation in prisoners noted in our study (1.9\%) was comparable with the average level of infection in the school-aged population in south-eastern Poland, in 2009-2012 $(2.01 \%)$ [16]. The incidence of P. humanus invasion in the general population noted for the last time in 2008 was $0.006 \%$ [17]. In our study, the prisoners exhibited a significantly higher percentage of S. scabiei var. hominis infections than the non-incarcerated population. In the analysed period, on average $2.3 \%$ of the Polish prisoners suffered from scabies, whereas the incidence of this disease in Poland noted in the general population in 2008 was $0.029 \%$ [17].

The higher prevalence of skin parasites, i.e., pediculosis and scabies, in confinement institutions may be a result of the persistent overcrowding of prisons found all around the globe, leading to an increase in the number of prisoners per cell. The minimum surface area per prisoner in Poland has been legally specified at $4 \mathrm{~m}^{2}$; however, it can be reduced to only $2 \mathrm{~m}^{2}$ for up to 90 days, while this value in most European Union countries is substantially higher: $9 \mathrm{~m}^{2}$ in Belgium and $10 \mathrm{~m}^{2}$ in the Netherlands and Spain [18]. Polish prisons mainly have multi-person (4-10 persons) cells, while single cells are intended for particularly dangerous prisoners or used for solitary confinement. Inmates can communicate with each other (e.g., in cells, at meals, on walks, and at work in the prison) and with prison Staff, medical personel, or visitors. An important issue in the functioning of prisons is to maintain discipline among prisoners. Therefore, it should be taken into account that intense pruritus associated with the above-mentioned dermatoses may lead to anxiety [19] and, combined with the accumulation of individuals in a small space, may promote aggressive behaviour.

Health care services provided to Polish prisoners are financed entirely from the state budget.

In accordance with the provisions in force in Poland, prisoners are subjected to preliminary, periodic, and control medical examinations documented in the convict's health records [20] and to sanitary procedures. Initial medical examinations are carried out by a general practitioner within 3 working days after imprisonment, while diagnostic examinations are performed within 14 days. This is a key time for elimination of ectoparasites, except for cases where the infestation is oligosymptomatic and/or the invasion is characterised by low intensity.

The spread of parasitic diseases of the skin, especially in the specific confinement conditions, is promoted by limited access to hygienic procedures. Non-working prisoners are entitled to only one bath with hot water a week, while women are entitled to two baths a week [18]. The conditions in cells that do not have adequate ventilation promote the out-of-host survival of scabies and louse [7,21-24]. Korycińska et al. described a positive correlation between air humidity and scabies incidence [25]. It should be mentioned that, in addition to the procedure of preliminary medical examinations followed by periodic and control check-ups, Polish prisoners have the right to make appointments mainly with the general practitioner [20]. Additionally, they are obliged to report their own disease and that of another convict to the prison service, which as a rule substantially accelerates the implementation of therapy for scabies and pediculosis.

As shown by the few available studies on the occurrence of pediculosis and scabies in prison conditions, a considerably higher prevalence of the infections than in Poland was recorded in prisons in Iran (0.9-5.2\% in the case of louse invasion, and 1.2-2.2\% in the case of scabies) [26-28]. Results obtained by Kuruvila et al. [29] in a district prison in Mangalore, India revealed that $63.6 \%$ of incarcerated individuals suffered from dermatoses and $8.0 \%$ of those had scabies and $6.6 \%$ pediculosis corporis. The literature also describes cases of scabies epidemics among prisoners in countries with a humid tropical climate, e.g., Tanzania and India, promoting infections [30,31]. Scabies is also the most common disease among prisoners in Cameroon [32].

Pediculosis has been shown to occur more frequently in drug-addicted prisoners and those sharing beds and bed linen as well as prisoners that bathe once a week or less frequently $[27,28]$. A study conducted by Nazari and coworkers showed that the occurrence of pediculosis was not affected by the educational level of the convict [26]; however, the knowledge about the epidemiology of pediculosis that could help prevent it is not by definition implemented during standard general education. That is why it should be propagated as a part of health education among prisoners. Adequate sanitary 
conditions, access to running water, reduction of the number of prisoners per cell, and detailed medical examinations of prisoners followed by several-day long quarantine may be important factors limiting the occurrence of scabies and pediculosis in confinement conditions [26-28,33,34].

Despite the existing medical supervision, ectoparasitoses in penitentiary institutions are still a current issue. Although the prevalence of scabies and pediculosis noted in our study is not considered epidemic (less than $4.0 \%$ for each), there is always a chance for improvement. Although our analysis did not confirm that the number of passes granted to prisoners had a significant impact on the prevalence of scabies and pediculosis in prisoners, newly convicted prisoners or those returning from leaves may be a source of the diseases. Therefore, special attention should be given to them both when they return to the facility and for the duration of the incubation period for these ectoparasitoses, i.e., 4-6 weeks in the case of scabies and 6-14 days in the case of pediculosis [35].

Studies conducted by Nazari and Azizi indicated association of the prevalence rate of scabies with the educational level; in subjects with a higher educational level, the prevalence of $S$. scabiei var. hominis invasion was over three times lower than in the illiterate group $(13.0 \%$ and $41.2 \%$, respectively) [36]. Among Polish prisoners, less than $6.0 \%$ are involved in both in-prison and out-of-prison schools. Obligatory educational programs can prevent the stigmatisation of the infected and dispel the common myths related to these diseases [37]. Making prisoners aware that they have a significant impact on limiting the invasion of ectoparasites in their own environment through preventive behaviours is beneficial from the social point of view [38]. It also gives prisoners a possibility to have an influence on their own existence, the lack of which is very severe in conditions of limited freedom. The results of preliminary research on the effects of health education on prisoners seem to be promising [39-42]. The effectiveness of health-promoting actions in reducing head lice infestation was confirmed in school students, another group particularly vulnerable to lice invasion e.g., $[43,44]$. Moreover, direct examination of indoor dust could be useful to detect the presence of mites and insects in an indoor environment [45].

\section{Conclusions}

Monitoring prisoners' health facilitates instantaneous response to emerging cases of scabies and pediculosis, thereby contributing to limitation of their prevalence in these facilities. However, despite constant medical supervision, these parasitoses still occur in confinement conditions. In order to minimise the problem, additional tools in the form of health education should be considered to address this major public health issue.

Author Contributions: Conceptualisation, K.B. and A.T.; methodology, K.B.; software, A.T., Z.Z.; validation, and formal analysis, K.B.; investigation, A.T.; resources, A.T.; data curation, A.T.; writing-original draft preparation, A.T., Z.Z., W.B., A.J.-K., and P.S.B.; writing-review and editing, K.B. and A.B.; visualisation, K.B., A.T., and Z.Z.; supervision, K.B; project administration, K.B. All authors have read and agreed to the published version of the manuscript.

Funding: This research received no external funding.

Acknowledgments: We acknowledge the help from the Directors of Central Board of Prison Service and District Inspectorate of the Prison Service in Lublin who have provided us with data for the scientific analysis.

Conflicts of Interest: The authors declare no conflict of interest.

\section{References}

1. Chosidow, O. Scabies and pediculosis. Lancet 2000, 355, 819-826. [CrossRef]

2. Ciftci, H.; Karaca, S.; Dogru, O.; Cetinkaya, Z.; Kulac, M. Prevalence of pediculosis and scabies in preschool nursery children of Afyon, Turkey. Korean J. Parasitol. 2006, 44, 95-98. [CrossRef] [PubMed]

3. Kouotou, E.A.; Nansseu, J.R.N.; Kouawa, M.K.; Zoung-Kanyi Bissek, A.C. Prevalence and drivers of human scabies among children and adolescents living and studying in Cameroonian boarding schools. Parasit. Vectors 2016, 9, 400. [CrossRef] [PubMed] 
4. Walker, S.L.; Lebas, E.; De Sario, V.; Deyasso, Z.; Doni, S.N.; Marks, M.; Roberts, C.H.; Lambert, S.M. The prevalence and association with health-related quality of life of tungiasis and scabies in schoolchildren in southern Ethiopia. PLoS Negl. Trop. Dis. 2017, 11, e0005808. [CrossRef] [PubMed]

5. Birkemoe, T.; Lindstedt, H.H.; Ottesen, P.; Soleng, A.; Næss, Ø.; Rukke, B.A. Head lice predictors and infestation dynamics among primary school children in Norway. Fam. Pract. 2016, 33, 23-29. [CrossRef]

6. Karakus, M.; Arici, A.; Töz, S.Ö.; Özbel, Y. Prevalence of Head Lice in Two Socio-economically Different Schools in the Center of Izmir City, Turkey. Turk. Parazitol. Derg. 2014, 38, 32-36. [CrossRef]

7. Arlian, L.G.; Morgan, M.S. A review of Sarcoptes scabiei: Past, present and future. Parasit. Vectors 2017, 10, 297. [CrossRef]

8. Cassell, J.A.; Middleton, J.; Nalabanda, A.; Lanza, S.; Head, M.G.; Bostock, J.; Hewitt, K.; Jones, C.I.; Darley, C.; Karir, S.; et al. Scabies outbreaks in ten care homes for elderly people: A prospective study of clinical features, epidemiology, and treatment outcomes. Lancet Infect. Dis. 2018, 18, 894-902. [CrossRef]

9. Smith, P.W.; Bennett, G.; Bradley, S.; Drinka, P.; Lautenbach, E.; Marx, J.; Mody, L.; Nicolle, L.; Stevenson, K. SHEA/APIC Guideline: Infection Prevention and Control in the Long-Term Care Facility. Infect. Control Hosp. Epidemiol. 2008, 29, 785-814. [CrossRef]

10. Falagas, M.E.; Matthaiou, D.K.; Rafailidis, P.I.; Panos, G.; Pappas, G. Worldwide prevalence of head lice. Emerg. Infect. Dis. 2008, 14, 1493-1494. [CrossRef]

11. Romani, L.; Steer, A.C.; Whitfeld, M.J.; Kaldor, J.M. Prevalence of scabies and impetigo worldwide: A systematic review. Lancet Infect. Dis. 2015, 15, 960-967. [CrossRef]

12. Mounsey, K.E.; Murray, H.C.; King, M.; Oprescu, F. Retrospective analysis of institutional scabies outbreaks from 1984 to 2013: Lessons learned and moving forward. Epidemiol. Infect. 2016, 144, 2462-2471. [CrossRef] [PubMed]

13. Mølle, L.; Gatherer, A.; Jürgens, R.; Stöver, H.; Nikogosian, H. Health in Prisons: A WHO Guide to the Essentials in Prison Health. WHO Regional Office Europe. 2007. Available online: http://www.euro.who.int/ __data/assets/pdf_file/0009/99018/E90174.pdf (accessed on 15 May 2020).

14. Stingeni, L.; Tramontana, M.; Principato, M.; Moretta, I.; Principato, S.; Bianchi, L.; Hansel, K. Nosocomial outbreak of crusted scabies in immunosuppressed patients caused by Sarcoptes scabiei var. canis. Br. J. Dermatol. 2020, 182, 498-500. [CrossRef] [PubMed]

15. Hart, G. Factors associated with pediculosis pubis and scabies. Genitourin. Med. 1992, 68, 294-295. [CrossRef] [PubMed]

16. Bartosik, K.; Buczek, A.; Zajac, Z.; Kulisz, J. Head pediculosis in schoolchildren in the eastern region of the European Union. Ann. Agric. Environ. Med. 2015, 22, 599-603. [CrossRef]

17. Czarkowski, M.P.; Cielebąk, E.; Kondej, B.; Staszewska, E. Infectious Diseases and Poisonings in Poland in 2008. Annual Report of National Institute of Public Health—National Institute of Hygiene-Department of Epidemiology. Warsaw 2009. Available online: http://wwwold.pzh.gov.pl/oldpage/epimeld/2008/Ch_2008. pdf (accessed on 3 May 2020).

18. Hygiene in Prisons in Individual European Countries-The Report. Available online: http://www.hfhr. pl/wp-content/uploads/2013/08/HFPC_raport_Raport_Higiena_w_zakladach_karnych.pdf (accessed on 5 May 2020).

19. Sanders, K.M.; Akiyama, T. The vicious cycle of itch and anxiety. Neurosci. Biobehav. Rev. 2018, 87, 17-26. [CrossRef]

20. Rogala, D.; Banach, A.; Jachimowicz-Gaweł, D.; Skinder, Ż.; Leźnicka, M. Health care system for persons detained in prisons in Poland. Hygeia Public Health 2013, 48, 441-448.

21. Mellanby, K.; Johnson, C.G.; Bartley, W.C.; Brown, P. Experiments on the Survival and Behaviour of the Itch Mite, Sarcoptes scabiei DeG. var. hominis. Bull. Entomol. Res. 1942, 33, 267-271. [CrossRef]

22. Arlian, L.G.; Runyan, R.A.; Achar, S.; Estes, S.A. Survival and infectivity of Sarcoptes scabiei var. canis and var. hominis. J. Am. Acad. Dermatol. 1984, 11, 210-215. [CrossRef]

23. Gallardo, A.; Mougabure Cueto, G.; Picollo, M.I. Pediculus humanus capitis (head lice) and Pediculus humanus humanus (body lice): Response to laboratory temperature and humidity and susceptibility to monoterpenoids. Parasitol. Res. 2009, 105, 163-167. [CrossRef]

24. Liu, J.M.; Wang, H.W.; Chang, F.W.; Liu, Y.P.; Chiu, F.H.; Lin, Y.C.; Cheng, K.C.; Hsu, R.J. The effects of climate factors on scabies. A 14-year population-based study in Taiwan. Parasite 2016, 23, 54. [CrossRef] [PubMed] 
25. Korycińska, J.; Dzika, E.; Kloch, M. Epidemiology of scabies in relation to socio-economic and selected climatic factors in north-east Poland. Ann. Agric. Environ. Med. 2019. [CrossRef]

26. Nazari, M.; Goudarztalejerdi, R.; Moradi, A. Investigation of pediculosis prevalence and associated factors in the central prison of Hamadan in 2013. Pajouhan Sci. J. 2015, 13, 13-20.

27. Shamsaddini, S.; Nasiri Kashani, M.; Sharifi, I.; Khajeh, K.A.M.; Pourlashkari, M. Prevalence of infectious skin diseases in the central prison of Kerman. Iran. J. Dermatol. 2000, 4, 19-25.

28. Roodsari, M.R.; Malekzad, F.; Roodsari, S.R. Prevalence of scabies and pediculosis in Ghenzel Hesar prison. Iran. J. Clin. Infect. Dis. 2007, 2, 87-90.

29. Kuruvila, M.; Shaikh, M.I.; Kumar, P. Pattern of dermatoses among inmates of district prison-Mangalore. Indian J. Dermatol. Venereol. Leprol. 2002, 68, 16-18.

30. Leppard, B.; Naburi, A.E. The use of Ivermectin in controlling an outbreak of scabies in a prison. Br. J. Dermatol. 2000, 143, 520-523. [CrossRef]

31. Singh, S.; Prasad, R.; Mohanty, A. High prevalence of sexually transmitted and blood-borne infections amongst the prisoners of a district jail in Northern India. Int. J. STD AIDS 1999, 10, 475-478. [CrossRef]

32. Demoures, B.; Nkodo-Nkodo, E.; Mbam-Mbam, L. Primary health care in a prison environment, the Cameroon experience. Sante 1998, 8, 212-216.

33. Willems, S.; Lapeere, H.; Haedens, N.; Pasteels, I.; Naeyaert, J.-M.; De Maeseneer, J. The importance of socio-economic status and individual characteristics on the prevalence of head lice in schoolchildren. Eur. J. Dermatol. 2005, 15, 387-392.

34. Manjrekar, R.R.; Partridge, S.K.; Korman, A.K.; Barwick, R.S.; Juranek, D.D. Efficacy of 1\% permethrin for the treatment of head louse infestations among Kosovar refugees. Mil. Med. 2000, 165, 698-700. [CrossRef] [PubMed]

35. Walton, S.F. The immunology of susceptibility and resistance to scabies. Parasite Immunol. 2010, 32, 532-540. [CrossRef] [PubMed]

36. Nazari, M.; Azizi, A. Epidemiological Pattern of Scabies and Its Social Determinant Factors in West of Iran. Health 2014, 6, 1972-1977. [CrossRef]

37. Clore, E.R. Dispelling the common myths about pediculosis. J. Pediatr. Health Care 1989, 3, 28-33. [CrossRef]

38. Ross, M.W. Pedagogy for prisoners: An approach to peer health education for inmates. J. Correct. Health Care. 2011, 17, 6-18. [CrossRef]

39. MacDonald, M.; Rabiee, F.; Weilandt, C. Health promotion and young prisoners: A European perspective. Int. J. Prison Health 2013, 9, 151-164. [CrossRef] [PubMed]

40. Donelle, L.; Hall, J. Health Promotion Body Maps of Criminalized Woman. J. Correct. Health Care. 2016, 22, 331-341. [CrossRef] [PubMed]

41. Maestre-Miquel, C.; Zabala-Baños, C.; García, J.A.; Antolín, J.M. Health education for prevalent problems in prison, Ocaña-I proyect (Spain). Rev. Esp. Sanid. Penit. 2016, 18, 86-94. [PubMed]

42. Keogh, B.; McBennett, P.; deVries, J.; Higgins, A.; O'Shea, M.; Doyle, L. Prisoners perceptions of a mental health wellness workshop. Int. J. Prison Health 2017, 13, 81-90. [CrossRef]

43. Moshki, M.; Zamani-Alavijeh, F.; Mojadam, M. Efficacy of Peer Education for Adopting Preventive Behaviors against Head Lice Infestation in Female Elementary School Students: A Randomised Controlled Trial. PLOS ONE 2017, 12, e0169361.

44. Yingklang, M.; Sengthong, C.; Haonon, O.; Dangtakot, R.; Pinlaor, P.; Sota, C.; Pinlaor, S. Effect of a health education program on reduction of pediculosis in school girls at Amphoe Muang, Khon Kaen Province, Thailand. PLoS ONE 2018, 13, e0198599. [CrossRef] [PubMed]

45. Stingeni, L.; Bianchi, L.; Hansel, K.; Neve, D.; Foti, C.; Corazza, M.; Bini, V.; Moretta, I.; Principato, M. Dermatitis caused by arthropods in domestic environment: An Italian multicentre study. J. Eur. Acad. Dermatol. Venereol. 2017, 31, 1526-1533. [CrossRef] [PubMed]

(C) 2020 by the authors. Licensee MDPI, Basel, Switzerland. This article is an open access article distributed under the terms and conditions of the Creative Commons Attribution (CC BY) license (http://creativecommons.org/licenses/by/4.0/). 